\title{
VLIV ORGANIZACE STÁTNÍ SPRÁVY NA (MÍSTNÍ) PŘÍSLUŠNOST SOUDU゚ VE SPRÁVNÍM SOUDNICTVÍ
}

\author{
LUKÁŠ POTĚŠIL
}

\begin{abstract}
The Influence of the Organization of State Administration on the (Local) Jurisdiction of Administrative Justice

This paper deals with changes that have taken place in the organization of state administration from the perspective of administrative justice and its local jurisdiction. To do so, the paper answers the fundamental question of whether the organization of state administration (in terms of the local jurisdiction of administrative authorities) and the organization of administrative courts (also in terms of their local jurisdiction) are related or not. In this context, it is worth considering whether the organization of administrative justice should follow the organization of the public/state administration as such and its trends or even the opposite and whether the two phenomena should not be independent of each other. The paper summarises the issue of the criteria for determining the local jurisdiction of administrative courts, the legal regulation of which has undergone certain developments, similar to the development of the legal regulation of the organization of the state administration. The question is whether any common indicators can be traced. The issue under examination is not only of a purely practical nature, such as the criteria for determining the local jurisdiction of an administrative court. It is related to the overall state of both the state administration and the administrative justice and their organization, and it offers several questions of a more general nature, such as the formal and informal impact of "its" regional court on the administrative authorities within its jurisdiction, the influence of their case law on "local administrative law", the question of the availability of administrative courts, or access to them, as well as their caseload. Overall, the paper discusses whether it is possible to find any relationship or rather consequences, arising from the local jurisdiction of administrative authorities, resulting of course from the form of the organization of the state administration, and the (non)corresponding local jurisdiction of the administrative justice. Possible de lege ferenda considerations in terms of the organization and local jurisdiction of the administrative justice are also mentioned.
\end{abstract}

Keywords: organization of state administration; administrative justice; local jurisdiction

Klíčová slova: organizace státní správy; správní soudnictví; místní příslušnost

DOI: $10.14712 / 23366478.2021 .42$

\section{ÚVOD}

Cílem tohoto př́spěvku je poukázat na uskutečněné proměny v organizaci státní správy z pohledu správního soudnictví a jeho místní př́slušnosti, a to i v širších 
souvislostech. Za tím účelem by příspěvek měl zodpovědět základní otázku, zda vůbec a pokud ano, tak jak spolu souvisí, nebo se dokonce vzájemně ovlivňuje, organizace státní správy (z pohledu územní působnosti správních orgánů) a organizace správních soudů (z pohledu jejich místní príslušnosti). V této souvislosti se nabízí úvaha, zda by organizace správního soudnictví měla (ná)sledovat organizaci státní správy jako takovou a její trendy, nebo dokonce přesně naopak, jakož i, zda by oba fenomény na sobě neměly být spíše nezávislé. $Z$ tohoto důvodu př́spěvek ponechává stranou organizaci samosprávy, která je dosti specifická. Výše uvedené skutečnosti jsou přitom aktuální a podstatné. Vycházíme-li z instrumentálního pojetí správního práva, jakožto souhrnu právních prostředkủ k ochraně subjektivních práv jednotlivců, je otázka soudní kontroly a př́stupu $\mathrm{k}$ soudu velmi důležitá.

Příspěvek shrnuje problematiku kritérií pro určení místní příslušnosti správních soudů, jejíž právní úprava prošla určitým vývojem, podobně, jako se vyvíjela právní úprava organizace státní správy. Otázkou je, zda lze vysledovat nějaké společné ukazatele. Zatímco „organizační“ změny ve správním soudnictví dosud sledovaly primárně zmírnění přetížení správního úseku Městského soudu v Praze, ne vždy těmto snahám odpovídaly legislativní aktivity na úrovni organizace státní správy, v jistých ohledech je dokonce př́mo popíraly. Tím se nastoluje otázka racionality norem správního práva, jakož i jejich vnitřní systémové soudržnosti a předvídatelnosti.

Zkoumaná problematika nemá jen ryze praktický nádech, jako jsou kritéria pro určení místní př́slušnosti správního soudu. Souvisí to s celkovým stavem jak státní správy, tak i správního soudnictví a jejich organizace, a nabízí se řada otázek obecnější povahy, jako je formální i neformální působení „svého“ krajského soudu na správní orgány v obvodu jeho působnosti, vliv jejich judikatury na „místní správní právo“, otázka dostupnosti správních soudů, resp. př́stupu k nim, jakož i jejich zatížení.

Příspěvek celkově pojednává o tom, zda lze najít nějaký vztah, potažmo spíše důsledky, plynoucí z územní působnosti správních orgánů, vyplývající ovšem z podoby organizace státní správy, a jemu posléze (ne)odpovídající místní př́slušnosti správního soudnictví. Zmíněny budou i možné úvahy de lege ferenda $\mathrm{z}$ hlediska organizace a místní př́slušnosti správního soudnictví.

\section{SPRÁVNÍ PRÁVO, STÁTNÍ SPRÁVA A SPRÁVNÍ SOUDNICTVÍ - OBECNÉ VYMEZENÍ A MOŽNÉ SOUVISLOSTI}

Správní právo je právním odvětvím, které tradičně obsahuje a reguluje veřejnou správu (tvořenou především státní správou a samosprávou), a to po stránce organizační a funkcionální. ${ }^{1}$ P. Průcha výstižně zmiňuje, že , správní právo je, ve smyslu jeho normativního vyjádření, právním rádem veřejné správy". ${ }^{2}$ Správní právo lze vnímat i ve smyslu instrumentálním, a to jako souhrn právních prostředků sloužících

1 Z učebnicové literatury shodně srov. PRŮCHA, P. Správní právo: obecná část. 8. vyd. Brno: Masarykova univerzita, 2012, s. 14; SLÁDEČEK, V. Obecné správní právo. 4. vyd. Praha: Wolters Kluwer ČR, 2019, s. 24; nebo KOPECKÝ, M. Správní právo: obecná část. 2. vyd. Praha: C. H. Beck, 2021, s. 6.

2 PRŮCHA, Správni právo..., s. 28. 
$\mathrm{k}$ omezení veřejné správy ${ }^{3}$ nebo také $\mathrm{k}$ zajištění ochrany práv jednotlivců před veřejnou správou. ${ }^{4} \mathrm{~V}$ daném kontextu tudíž nemusí být tolik delikátní otázka, zda součástí správního práva ${ }^{5}$ má být i problematika správního soudnictví. Pro něj je totiž klíčovou jeho soudní podstata a je to právě soudnictví, které bývá zmiňováno při uplatnění odčítací metody $\mathrm{v}$ rámci negativního vymezení veřejné správy. ${ }^{6}$ Vyjdeme-li z toho, že správní právo (tradičně) zahrnuje ${ }^{7}$ také správní soudnictví, oba fenomény správního práva v podobě veřejné správy a existence správního soudnictví, jakožto specifického projevu tzv. soudní kontroly veřejné správy, nastolují řadu možných souvislostí. Ty mohou být dány $\mathrm{v}$ rovině funkcionální, nebo organizační. $\mathrm{V}$ tomto př́spěvku se dále budu zabývat právě možnými souvislostmi po organizační stránce.

Jestliže je pro účely tohoto př́spěvku záměrně ponechána stranou samospráva a její možné vztahy a souvislosti se správním soudnictvím, je namístě ve stručnosti přiblížit státní správu. Tu lze charakterizovat jako klíčovou součást veřejné správy, která je zabezpečována státem a jeho orgány, a to bud' přímo, nebo nepř́mo (v tzv. přenesené působnosti v př́ípadě orgánů územních samosprávných celků nebo na základě zákonné delegace u fyzických a právnických osob). ${ }^{8}$ Státní správa v organizačním ${ }^{9}$ pojetí tvoří soustavu vykonavatelů (orgánů) státní správy (označovaných často jako správní úráady), ${ }^{10}$ přičemž jsou pro ni typické instanční vztahy nadř́zenosti a podřízenosti (vycházející z uplatnění principu vertikální dekoncentrace). ${ }^{11}$ Pro státní správu je dále př́značné, že je vykonávána jménem subjektu/nositele (státu), jeho jménem, na jeho účet a také na jeho odpovědnost. Zmínit lze i takové atributy státní správy, jako je dlouhodobost či trvalost. Pro účely tohoto př́spěvku je nicméně klíčové organizační pojetí státní správy, resp. podoba její organizace, jak o tom pojednává následující část.

Při vymezení správního soudnictví je třeba v první řadě zdůraznit jeho ochranný charakter, který je předurčen již čl. 90 Ústavy. Podle něj je úkolem soudů obecně ochrana

3 Ve smyslu vytýčení mezí či mantinelů; k tomu mj. srov. čl. 2 odst. 3 nebo čl. 79 odst. 1 Ústavy a čl. 2 odst. 4; nebo čl. 36 Listiny základních práv a svobod.

${ }^{4}$ Domnívám se, že oba uváděné př́stupy ke správnímu právu se nijak vzájemně nevylučují a oba v podstatě obsahují totéž, pouze poněkud jiným způsobem. Zmíněný „ochranný“ charakter je typicky zmiňován v britském právním prostředí, $\mathrm{k}$ tomu (včetně odlišení od vývoje středoevropského) srov. SORDI, B. Révolution, Rechtsstaat and the Rule of Law: historical reflections on the emergence and development of administrative law. In: ACKERMANN, S. R. - LINDETH, P. L. - EMERSON, B. (eds.). Comparative Administrative Law. 2nd ed. Cheltenham: Edward Elgar Publishing, 2017, s. 23-37.

5 Zde (a dále $\mathrm{v}$ textu) ovšem spíše $\mathrm{v}$ rovině vědy správního práva jako vědecké disciplíny zabývající se správním právem.

${ }^{6}$ Srov. PRƯCHA, Správní právo..., s. 56; SLÁDEČEK, Obecné správní právo, s. 35; nebo KOPECKÝ, Správní právo..., s. 3.

7 Již od počátku ustavení správního soudnictví na našem území (1867, resp. od roku 1876) bylo o správním soudnictví pojednáváno především v publikacích věnovaných správnímu právu (srov. kupř. ČÍŽEK, K. Obrys zř́zení správního. Praha: Jindř. Mercyho sklad, 1888, s. 74 a násl.). Tento př́stup přetrval do období 1. republiky po roce 1918 (srov. kupř. HOETZEL, J. Československé správní právo: část všeobecná. Praha: Melantrich, 1934, s. 375 a násl.); prričemž po znovuobnovení správního soudnictví po roce 1989, resp. od roku 1992 je tomu tak nadále, o čemž ostatně svědčí i obsah výše uvedených učebnic správního práva.

8 SLÁDEČEK, Obecné správní právo, s. 26.

9 P. Průcha dodává, že pojem „organizace“ je pojmem mnohovýznamovým - blíže srov. PRŮCHA, Správní právo..., s. 162.

$10 \mathrm{~K}$ tomu srov. čl. 79 Ústavy; nebo také HENDRYCH, D. Správní úřad a správní orgán v českém právu. Právni fórum. 2004, roč. 1, č. 5, s. 199 a násl.

11 PRŮCHA, Správní právo..., s. 166. 
(subjektivních) práv. To je $\mathrm{v}$ případě správního soudnictví blíže potvrzeno a rozvedeno (s ohledem na veřejnoprávní charakter subjektivních práv) v § 2 zákona č. 150/2002 Sb., soudní ráa správní, ve znění pozdějších předpisů (dále též jako „soudní řád správní“ nebo „s. ř. s."). ${ }^{12}$ Tak, jako je trvající potíž s presnějším vymezením veřejné správy, do jisté míry pojmově je dána shodná potíž při vymezení správního soudnictví, které v mnoha ohledech na veřejnou správu ,navazuje“. Je řada možných př́stupů k explikaci ${ }^{13}$ fenoménu správního soudnictví. ${ }^{14} \mathrm{Z}$ uvedených důvodů lze ve stručnosti uvést, že správní soudnictví je specifickou a nezávislou složkou státní moci, jejímž účelem je ochrana veřejných subjektivních práv fyzických a právnických osob, do nichž bylo zasaženo ze strany veřejné správy.

Státní správa a správní soudnictví jsou poměrně klíčovými prvky správního práva. Oba spolu souvisí tak, že správní soudnictví vykonává následnou soudní kontrolu státní správy a poskytuje soudní ochranu vůči předchozím negativním zásahům ze strany státní správy. Jednotlivé „výstupy“ státní správy jsou tudíž pod kontrolou správního soudnictví. Jinými slovy, je to právě státní správa, která vytváří potenciální případy pro správní soudnictví a současně je to správní soudnictví, které na jejich základě poskytuje soudní ochranu tam, kde došlo k negativnímu zásahu do právní sféry jednotlivce.

Protože př́spěvek se zaměřuje na vztah organizace státní správy a správního soudnictví, otázkou je, zda by oba systémy měly po organizační stránce vykazovat podobné rysy, či nikoliv. Osobně jsem toho názoru, že by jistá korelace být měla, nicméně více je tato skutečnost rozvedena dále $\mathrm{v}$ textu. Tato otázka je podle mého spojena i s př́stupem k soudní ochraně.

\section{ORGANIZACE STÁTNÍ SPRÁVY A JEJÍ ÚZEMNÍ PŮSOBNOST}

Nahlížíme-li na organizaci státní správy, máme před sebou hierarchickou soustavu ${ }^{15}$ tvořenou ústřední, ${ }^{16}$ celostátní a nižší, obvykle shora uvedeným podřízenou, úrovní, představovanou územním členěním, resp. územní státní správou.

12 Nedávná (kasační) rozhodnutí Nejvyššího správního soudu vydaná v souvislosti s přezkumem tzv. pandemických mimořádných opatření podle $\S 13$ zákona č. 94/2021 Sb., o mimořádných opatřeních při epidemii covidu-19, jsou naprosto ukázkovým př́kladem ochranného působení správního soudnictví. Soudy, jakkoliv si bezesporu byly jasně vědomy negativní situace, nezohlednily na prvním místě zájem státu na ochraně veřejného zdraví a s tím spojená omezení, nýbrž naopak zájem jednotlivce na ochranu před negativními zásahy do jeho právní sféry. Lze vyslovit zjednodušující tezi, že správní soudnictví je sice složkou veřejné/ státní moci, nicméně v podstatě funguje ,protistátně“. Ostatně i to je názorná ukázka toho, jak a proč je správní soudnictví důležité. Plně se tak potvrzují slova E. Háchy, podle něhož správní soudnictví je ,,instituce pro ochranu individua proti výkonné moci státni a nikoliv jako všeobecná kontrola zákonnosti bez vztahu k jednotlivci“. (HÁCHA, E. Nejvyšší správní soud. In: Slovník československého práva veřejného. Svazek II. Brno: Polygrafia - Rudolf M. Rohrer, 1932, s. 845).

13 Shodně srov. HÁCHA, E. Správní soudnictví. In: Slovník československého práva veřejného. Svazek IV. Brno: Polygrafia - Rudolf M. Rohrer, 1932, s. 589.

14 M. Kopecký poukazuje na některé charakteristické rysy a modely správního soudnictví, v nichž jsou zastoupeny právě mnohé pojmové znaky správního soudnictví. Blíže k této problematice srov. KOPECKÝ, Správní právo..., s. 469-472.

15 Srov. SLÁDEČEK, Obecné správni právo, s. 252.

$16 \mathrm{~K}$ problematice změn ústřední státní správy srov. SLÁDEČEK, V. Ústřední státní správa ve víru změn. Acta Universitatis Carolinae Iuridica. 2010, Vol. LVI, č. 1, s. 105 a násl. 
Obecně je nutno uvést, že organizace státní správy by měla vyhovovat jistým požadavkům, a to nikoliv výlučně těm, které pocházejí př́mo z ,interna“ státní správy. Pokud se D. Hendrych ${ }^{17}$ zmiňoval o konceptu dobré správy v jejím organizačním pojetí, můžeme sem zařadit také srozumitelnou a předvídatelnou organizační strukturu státní správy z pohledu jejích adresátů, či chceme-li klientů, a to včetně snadného přístupu k ní. Nelze rovněž opomenout ani tradiční principy výstavby organizace veřejné správy, jako je především princip územní (v kontrapozici s principem věcným či funkčním).

Územní (teritoriální) princip vymezuje působnost jednotlivých vykonavatelů/orgánů ve vztahu k určitému území, přičemž literatura dodává, že územní princip vymezuje působnost vykonavatele obecně, tj. pro všechny či širší okruh záležitostí (tzv. všeobecná působnost) na daném území. ${ }^{18} \mathrm{~V}$. Sládeček výstižně dodává, že ,,rozeznáváme působnost celostátní, tj. správní úr̆ad působi na celém území státu, a místní (regionální, oblastní), kdy správní úřad vykonává působnost toliko na části státního území. Zpravidla je kompetence vymezena v souladu s územním (správni okresy a kraje) či se samosprávným členěním státu (území samosprávných krajů a hl. m. Prahy), tedy i na různém prostorovém rozsahu (regionální či lokální). "19 Věcný (rezortní) princip naopak vymezuje působnost z věcného hlediska, specializovaně pro určitou oblast/agendu/odvětví veřejné správy. $\mathrm{V}$ daném ohledu se v praxi nicméně často setkáváme s kombinací územního a věcného principu. ${ }^{20}$ Výsledkem je, že určitý orgán vykonává užší nebo širší okruh působnosti na určitém území, pro který se obvykle používá označení „správní obvod".

Z pohledu organizace územní státní správy a vymezení zmíněných správních obvodů je klíčový zákon č. 51/2020 Sb., o územně správním členění státu. ${ }^{21}$ Tento zákon nabyl účinnosti 1. 1. 2021 a nahradil již legendární zákon č. 36/1960 Sb., o územním členění státu. Cílem tohoto předpisu bylo sjednotit dosavadní dvojí (a nepřehledné) územní členění státu z hlediska státní správy a samosprávy, a to ve prospěch správních obvodů, které se kryjí s územím územních samosprávných celků. ${ }^{22} \mathrm{~V}$ návaznosti na to zákon o územně správním členění státu obsahuje dvojí členění. To první je označováno jako „základní“23 a vychází z existence správních obvodů krajů a obcí s rozšířenou působností. V daném ohledu se nejedná o zcela převratnou změnu, nýbrž kodifikování již dříve dosaženého stavu, resp. završení postupných tendencí z hlediska sjednocování správ-

17 HENDRYCH, D. O organizačních předpokladech dobré správy. Správní právo. 2007, roč. XL, č. 4-5, s. 201 a násl.

18 PRŮCHA, Správni právo..., s. 168; SLÁDEČEK, Obecné správní právo, s. 266; nebo KOPECKÝ, Správní právo..., s. 79.

19 SLÁDEČEK, Obecné správní právo, s. 264.

20 Shodně srov. tamtéž, s. 267.

${ }^{21}$ K vývojovým tendencím v oblasti organizace státní správy srov. SLÁDEČEK, V. - FRUMAROVÁ, K. MELOTÍKOVÁ, P. (eds.). Organizace státní správy: vývojové tendence. Praha: Leges, 2014.

22 Blíže srov. důvodovou zprávu.

23 V jeho intencích se území České republiky pro výkon státní správy primárně člení na správní obvody krajů. Ty jsou dány ústavním zákonem č. 347/1997 Sb., o zřízení vyšších územně samosprávných celků. Správní obvod kraje se posléze člení na správní obvody obcí s rozšířenou působností. Správní obvod obce s rozšířenou působností je vymezen výčtem území obcí a vojenských újezdů, přičemž území obce a území vojenského újezdu je vymezeno hranicí jednoho nebo více souvislých katastrálních území. 
ních obvodů krajů s územím krajů jakožto vyšších územně samosprávných celků. ${ }^{24}$ Tím se odstraňuje mj. tzv. dvojí krajské členění. Oproti tomu „dalši‘“ územně správní členění nadále zachovává okresy, které jsou nově vymezeny prostřednictvím správních obvodů obcí s rozšířenou působností, čímž se má zajistit skladebnost jejich území. ${ }^{25}$

Organizační struktura státní správy není samoúčelná a zaměřená dovnitř. $Z$ procesního hlediska jsou shora uvedené skutečnosti a východiska podstatná pro určení věcné a místní př́islušnosti správních orgánů, resp. z nich věcná a místní příslušnost správních orgánů vychází.

Určení (věcné a místní) př́slušnosti znamená nalezení konkrétního orgánu z celé organizační soustavy státní správy. Věcná př́íslušnost stanoví typově/druhově ten orgán, kterému byla svěrena pravomoc a působnost $\mathrm{k}$ realizaci určité správní aktivity, a to zákonem či na základě zákona. ${ }^{26}$ Klíčové je z hlediska věcné př́slušnosti vymezení předmětu řízení. Podstatou místní príslušnosti, která navazuje na určení věcné příslušnosti, obecně je, že prostřednictvím různých kritérií pomáhá určit, který konkrétní věcně př́slušný orgán je z hlediska své územní působnosti oprávněn (ale také povinen) se určitou věcí zabývat. ${ }^{27}$ Je to právě kritérium místní př́slušnosti, které vychází z toho, že věcně příslušných je několik vykonavatelů, což je dáno právě tím, že působí na určitém správním obvodu. V př́ípadě správních orgánů ústředních či s celostátní působností obvykle problémy s místní př́slušností dány nejsou. ${ }^{28}$ Naopak určení místně př́slušného správního orgánu je klíčovým prvkem v případě územní státní správy, kde jednotlivé správní orgány vykonávají svoji působnost ve „svém“ správním obvodu.

$24 \mathrm{~K}$ tomu blíže srov. SLÁDEČEK, V. Hlavní mezníky a tendence ve vývoji organizace veřejné správy. In: SLÁDEČEK, V. - FRUMAROVÁ, K. - MELOTÍKOVÁ, P. (eds.). Organizace státni správy: vývojové tendence. Praha: Leges, 2014, s. 10.

25 Se skutečností, že správní obvody okresů nejsou zcela prázdnou kategorií, jsme se mohli všichni osobně (a nedobrovolně) seznámit v souvislosti s omezeními danými onemocněním covid-19, kdy byl omezen volný pohyb jak mezi okresy, tak i v rámci okresů samotných. Blíže srov. usnesení vlády ze dne 26. 2. 2021, č. 216 o přijetí krizových opatření s účinností od 1. 3. 2021 do 21. 3. 2021.

26 Jak uvádí Nejvyšší správní soud v rozsudku ze dne 23. 4. 2014, č. j. 6 Ads 87/2013-131, , institut věcné př́slušnosti slouži k určení, který z orgánů nadaný obecně pravomocí rozhodovat o právech a povinnostech osob ve veřejné správě bude rozhodovat v konkrétni věci. Věcnou př́slušnost samozrejmě nelze vymezovat individuálně, tj. s ohledem na každý jednotlivý společenský vztah, nýbrž druhově: právo vytvář́ okruhy věci spojených vnitřni podobností, definuje je společnými znaky a tyto skupiny obsahově spřrizněných věcí pak svěruje k rozhodování jednotlivým správním orgánům. " Dodejme, že věcná př́islušnost zahrnuje také příslušnost instanční z hlediska určení nadřizeného orgánu a někdy i prríslušnost funkční ohledně určení konkrétního orgánu či organizačního článku správního orgánu.

27 Je třeba dodat, že v některých agendách (kupř. vydávání občanských průkazů) se postupně kritérium místní př́slušnosti vytrácí, resp. opouští, což vede mj. k určité konkurenci mezi správními orgány z hlediska uspokojování potřeb svých klientů.

28 Jistým specifikem v daném ohledu je kupř. koncepce Úřadu práce ČR. Ten je sice správním úřadem s celostátní působností, jak výslovně upravuje $\S 1$ odst. 1 zákona č. 73/2011 Sb., nicméně podle $\S 2$ odst. 1 písm. b) téhož zákona jsou jeho součástí také tzv. krajské pobočky, jejichž správní obvody jsou totožné s územím krajů jako vyšších územních samosprávných celků. Blíže k této problematice, jakož i tzv. územním pracovištím, srov. KOPECKÝ, M. K institutu pracovišt' a jiných územních útvarů správních úřadů. Správní právo. 2013, roč. XLVI, č. 2, s. 88 a násl. 
Podpůrná ${ }^{29}$ kritéria pro určení věcné a místní př́slušnosti obsahuje $\S 10$ a $11^{30}$ správního rádu č. 500/2004 Sb. ${ }^{31}$ Zatímco nedostatek místní př́slušnosti př̌edstavuje procesní pochybení, které může založit nezákonnost vydaného aktu, potažmo důvod $\mathrm{k}$ jeho zrušení, ${ }^{32}$ nedostatek věcné príslušnosti podle $\S 77$ odst. 1 správního řádu způsobuje nicotnost aktu, který byl nepř́islušným orgánem vydán.

Je evidentní, že vyřešení věcné a místní př́islušnosti má poměrně široké dopady a důsledky. V kontextu práva na soudní ochranu, které je obecně zakotveno v čl. 36 odst. 2 Listiny základních práv a svobod, se nicméně dostáváme $\mathrm{k}$ otázce př́stupu $\mathrm{k}$ soudu a (ne)návaznosti organizace státní správy a organizace správního soudnictví.

\section{ORGANIZACE SPRÁVNÍHO SOUDNICTVÍ A JEHO MÍSTNÍ P̌̌́SLUŠNOST}

Stávající organizace správního soudnictví je výsledkem určitého kompromisu, ${ }^{33}$ podle něhož sice byl ${ }^{34}$ zřízen samostatný Nejvyšší správní soud, avšak nižší článek celé soustavy v podobě krajských soudů není institucionálně samostatný, nýbrž je součástí obecného soudnictví. To zahrnuje jak výhody, tak nevýhody. S jistou mírou zjednodušení lze konstatovat, že na úrovni krajských soudů si správní soudnictví ,ppůjčuje“ soudy, resp. soudce od soudnictví obecného. ${ }^{35}$ Osobně jsem přesvědčen, že toto kompromisní řešení je (i z dlouhodobého hlediska) problematické. Bližší rozbor ovšem přesahuje zaměření tohoto př́spěvku.

Vyjdeme-li z toho, že správní soudnictví je po organizační stránce zajišt’ováno krajskými soudy a Nejvyšším správním soudem, dostáváme se ke kritériím pro určení jejich místní príslušnosti. I v případě správního soudnictví je místní př́slušnost předznamenána př́slušností věcnou, která je (před)určena pravomocí správních soudů především podle $\S 4 \mathrm{~s}$. ř. s. S ohledem na skutečnost, že ve správním soudnictví působí (pouze) krajské soudy a Nejvyšší správní soud, ${ }^{36}$ jsou pravidla pro určení věcné příslušnosti poměrně jasně daná.

29 S ohledem na subsidiární působnost správního řádu podle jeho $§ 1$ odst. 2.

30 Místní příslušnost se určuje v návaznosti na povahu předmětu správního řízení (zda jde o činnost - místo činnosti, nemovitost - poloha nemovitosti, podnikatelská činnost - místo podnikání a v ostatních př́padech místem trvalého pobytu nebo sídla).

31 Kromě uvedených ustanovení je třeba rovněž zohlednit $\$ 130$ až 133 správního řádu.

32 Shodně srov. POTĚŠIL, L. a kol. Správní řád: komentář. 2. vyd. Praha: C. H. Beck, 2020, s. 82 a judikaturu zde uvedenou.

33 Srov. MIKULE, V. in: HENDRYCH, D. a kol. Správní právo: obecná část. 9. vyd. Praha: C. H. Beck, 2016, s. 373.

34 Srov. § 11 odst. 1 s. r. s.

35 Slabinou tohoto řešení je, že se sice předpokládá specializace na úseku správního soudnictví (srov. § 29 písm. c) zákona č. 6/2002 Sb., o soudech a soudcích), jakož jsou dány podmínky pro přidělování nových soudců (srov. § 121 odst. 1 s. ř. s.), nicméně taková specializace není na úrovni krajských soudů zaručena, resp. není vyloučeno, že soudce správního úseku krajského soudu se může podílet i na jiných úsecích, což je věcí rozvrhu práce, stejně jako že kterýkoliv soudce krajského soudu může být rozvrhem práce zařazen do správního úseku. Blíže srov. ŠIMÍČEK, V. a kol. Soudní řád správní: komentár̆. Praha: Leges, 2014, s. 1098; nebo KÜHN, Z. a kol. Soudní ř́d správni: komentářr. Praha: Wolters Kluwer ČR, 2019, s. 1044.

36 Shodně srov. $§ 3$ s. ř. s. 
Z hlediska věcné př́ílušnosti soudů ve správním soudnictví je základním pravidlem věcná př́slušnost krajského soudu, zatímco věcná příslušnost Nejvyššího správního soudu je výjimkou. ${ }^{37}$

Určení místní př́islušnosti je v př́ípadě Nejvyššího správního soudu poměrně snadné, nebot' se jedná o orgán s celostátní působností. $Z$ toho důvodu právní úprava jeho místní př́slušnost nijak blíže neupravuje. Proto má význam věnovat se kritériím pro určení místní př́slušnosti na úrovni krajských soudů, které působí ve správním soudnictví. ${ }^{38}$

Právní úprava regulující pravidla pro určení místní př́islušnosti krajských soudů je obsažena v $§ 7$ odst. 2 a 3 s. r. s., a to kombinací obecné a speciální místní př́slušnosti. Výhradně pro oblast „sociálního“ správního soudnictví je podle $\S 7$ odst. 3 s. ř. s. místní př́slušnost dána bydlištěm ${ }^{39}$ nebo sídlem navrhovatele, resp. místem, kde se zdržuje, ${ }^{40}$ vůči obvodu krajského soudu, a to výčtem jednotlivých případů, resp. obecným předmětem rrízení. Tím je v soudním řádu správním nastavena výjimka z obecného pravidla pro určení místní př́slušnosti. ${ }^{41}$

Podle obecného pravidla je k ř́zení místně př́slušný krajský soud, v jehož obvodu je sídlo správního orgánu, který ve věci vydal rozhodnutí v prvním stupni, nebo jinak zasáhl do práv toho, kdo se u soudu domáhá soudní ochrany.

Praktický problém se často skrývá v tom, že musí jít o správní orgán, ve smyslu jeho legislativní zkratky podle $\S 4$ odst. 1 písm. a) s. ř. s. ${ }^{42}$ Toto obecné pravidlo uvedené

37 Srov. $§ 7$ odst. 1 s. r. s. Př́́mo podle soudního řádu správního (pomineme-li základní náplň v rovině kasační stižňnosti a řízení o ní, jakož i další agendy vycházející z postavení Nejvyššího správního soudu jako vrcholného soudního orgánu při rozhodování kupř. o sporech o věcnou nebo místní př́slušnost nebo př̀ rozhodování o vyloučení soudce z důvodu podjatosti), je Nejvyšší správní soud věcně příslušný k vedení řízení o rozpuštění politické strany nebo politického hnutí, pozastavení nebo znovuobnovení jejich činnosti (srov. § 94 odst. 1 písm. b) ve spojení s § 95 s. ř. s.) nebo o kompetenčních žalobách (srov. § 97 odst. 4 s. ř. s.). Věcnou př́slušnost Nejvyššího správního soudu zavádějí také jednotlivé zvláštní zákony (jako je kupř. § 58 odst. 1 zákona č. 62/2003 Sb., o volbách do Evropského parlamentu; § 68 zákona č. 275/2012 Sb., o volbě prezidenta republiky; § 88 zákona č. 247/1995 Sb., o volbách do Parlamentu České republiky; § 35h stavebního zákona č. 183/2006 Sb.; nebo již zmiňovaný § 13 zákona č. 94/2021 Sb., o mimořádných opatřeních při epidemii covidu-19).

38 Soudní řád správní v nedávné době zavedl výlučnou/výhradní/kauzální (místní a věcnou) př́slušnost některých krajských soudů, a to s ohledem na specifika předmětu ř́zení. Podle $§ 7$ odst. 4 s. ř. s. je to Krajský soud v Ostravě (ve věcech proti rozhodnutí o umístění nebo povolení staveb dopravní infrastruktury) a podle § 101e odst. 4 s. ř. s. je to Městský soud v Praze (ve věcech návrhu na zrušení služebního předpisu).

39 Právní úprava při určení místní př́slušnosti tuto neodvozuje od kritéria místa trvalého pobytu, jakožto evidenčního údaje podle zákona č. 133/2000 Sb., o evidenci obyvatel, nýbrž od bydliště, resp. faktického stavu. K této problematice blíže srov. usnesení Nejvyššího správního soudu ze dne 20. 3. 2013, č. j. Nad 17/2013-16.

40 K tomu srov. usnesení Nejvyššího správního soudu ze dne 8. 6. 2004, č. j. Nad 79/2004-1, č. 371/2004 Sb. NSS.

41 Vyloučeno není, aby vlastní kritéria pro určení místní př́islušnosti správního soudu obsahovaly zvláštní zákony, a to pro jednotlivé agendy (srov. kupř. § 32 odst. 3 zákona č. 325/1999 Sb., o azylu; § 172 odst. 7 zákona č. 326/1999 Sb., o pobytu cizinců; § 12a zákona č. 456/2011 Sb., o Finanční správě ČR; nebo subsidiárně k soudnímu řádu správnímu $§ 89$ odst. 2 zákona č. 582/1991 Sb., o organizaci a provádění sociálního zabezpečení).

42 Nejvyšší správní soud v rozsudku ze dne 11. 2. 2019, č. j. 5 As 379/2018-17, shrnul svoji judikaturu k předmětné problematice a uvedl, že ,vždy je třeba vycházet ze základního pravidla, že za ,správní orgán 'lze považovat orgán moci výkonné, orgán územniho samosprávního celku, jakož i fyzickou nebo právnickou osobu nebo jiný orgán, pokud jim bylo svěřeno rozhodování o právech a povinnostech fyzických a právnických osob v oblasti veřejné správy [\$ 4 odst. 1 písm. a) s. ř s.]. Organizační složka správního orgánu může být správním orgánem rozhodujicím v prvním stupni pouze tehdy, svěruje-li jí 
v $§ 7$ odst. 2 s. ř. s. má důležitý praktický dovětek, podle něhož, má-li správní orgán sídlo mimo obvod svojí působnosti, platí, že má sídlo v obvodu svojí působnosti. ${ }^{43}$ Tím je zvolena vazba mezi místní příslušností správního orgánu, správním obvodem, doprovázeným umístěním jeho sídla, vưči místní příslušnosti správního soudu, resp. jeho obvodem působnosti. Je třeba dodat, že soudní řád správní neupravuje specifické soudní obvody (tzv. soudní kraje), což je uvedeno blíže dále v textu.

Předmětná právní úprava pro určení místní příslušnosti krajských soudů nicméně od účinnosti soudního řádu správního v roce 2003 doznala jistých změn, a to jak v případě obecné, tak i speciální místní příslušnosti. Zatímco obecná pravidla pro určení místní příslušnosti uvedená v $\$ 7$ odst. 2 s. ř. s. se změnila ,až“ s účinností k 1. 1. 2012 tzv. velkou novelou ${ }^{44}$ provedenou zákonem č. 303/2011 Sb., již dříve docházelo k dílčím změnám v pravidlech pro určení speciální místní př́íslušnosti, resp. tato byla postupně rozšiřována na další sociální oblasti. ${ }^{45}$

právní předpis určité samostatné rozhodovaci pravomoci (srov. rozsudek Nejvyššiho správního soudu ze dne 16. 7. 2008, č. j. 3 Ans 8/2008-84). Pokud však zákon nevymezuje organizačním složkám správního orgánu s celostátní působnosti (vnitřním organizačním jednotkám) samostatnou rozhodovaci pravomoc, nemohou takové organizačni jednotky ziskat postavení správního orgánu rozhodujícího v prvním stupni

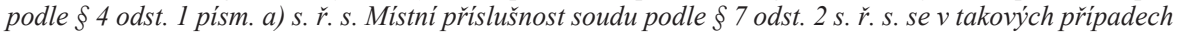
bude rídit sídlem správního orgánu s celostátni působností, nikoli sídlem jeho vnitřní organizační jednotky (srov. např. rozsudek Nejvyššiho správního soudu ze dne 15. 2. 2012, č.j. 6 Ads 15/2011-143, nebo také usnesení Nejvyššiho správního soudu ze dne 28. 11. 2012, č. j. Nad 81/2012-71). [...]. " Proto, podle usnesení Nejvyššího správního soudu ze dne 4. 10. 2019, č. j. Nad 171/2019-52, č. 3939/2019 Sb. NSS, regionálním pracovištím Agentury ochrany př́rody a krajiny České republiky zákon nesvěřil samostatné rozhodovací pravomoci. K řízení o žalobě proti rozhodnutí o povolení výjimky ze zákazů u chráněných krajinných oblastí, které v prvním stupni vydala Agentura ochrany př́rody České republiky podle $§ 78$ odst. 3 písm. h) zákona č. 114/1992 Sb., o ochraně přírody a krajiny, je proto v souladu s $\S 7$ odst. 2 s. ̌r. s. místně příslušný krajský soud, v jehož obvodu sídlí ústř̌edí Agentury (Městský soud v Praze). Nejvyšší správní soud vyšel z toho, že fakticky se sice Agentura ochrany př́rody a krajiny vnitřně člení, ale je tomu tak na základě jejích vnitřních předpisů, a nikoliv na základě zákona, který agenturu považuje jako celek za správní orgán s celostátní působností.

43 Dovětek, resp. fikce, která přesouvá sídlo, jež se nachází mimo obvod jeho působnosti do obvodu působnosti tohoto správního orgánu, má za cíl snížení zátěže Městského soudu v Praze s ohledem na skutečnost, že řada správních orgánů (pro správní obvod Středočeského kraje) má své sídlo v Praze. Týká se to nejenom Krajského úřadu Středočeského kraje, ale i dalších orgánủ př́ímé státní správy. Jak k tomu dodává usnesení Nejvyššího správního soudu ze dne 12. 12. 2013, č. j. Nad 69/2013-78, za situace, kdy př́islušný inspektorát České obchodní inspekce působí ve dvou krajích (Středočeském kraji a hlavním městě Praze), má sídlo v jednom z nich (v Praze) a správní delikt byl spáchán ve Středočeském kraji, jsou naplněny podmínky pro aplikaci $§ 7$ odst. 2 věty druhé s. ř. s., podle něhož, má-li tento správní orgán sídlo mimo obvod své působnosti, platí, že má sídlo v obvodu své působnosti. Místně př́islušným soudem k projednání věci je proto Krajský soud v Praze. Naopak by tomu bylo, kdyby šlo o delikt na území hlavního města Prahy, kde by byla dána příslušnost Městského soudu v Praze, nebot' zde správní orgán sídlí v obvodu své působnosti (srov. usnesení rozšířeného senátu Nejvyššího správního soudu ze dne 2. 8. 2016, č. j. Nad 272/2016-58, č. 3449/2016 Sb. NSS). Je nutno konstatovat, že podobně je zvolena konstrukce vnitřní organizace kupř. u Státní zemědělské a potravinářské inspekce podle $§ 1$ odst. 2 zákona č. 146/2002 Sb., o Státní zemědělské a potravinářské inspekci. Podrobněji k této problematice srov. ŠIMÍČEK, $c$. $d$., s. 59-60; obecněji potom srov. KOPECKÝ, K institutu pracovišt' a jiných územních útvarů správních úradů; nebo KOPECKÝ, Správní právo..., s. 89-90.

$44 \mathrm{~K}$ přiblížení této novely mj. srov. SLÁDEČEK, V. - MELOTÍKOVÁ, P. (eds.). Aktuální otázky správního soudnictví (zejména v souvislosti s novelou soudního řádu správního provedenou zákonem č. 303/2011 Sb.). Praha: Leges, 2021.

45 Srov. novelu provedenou zákonem č. 375/2005 Sb. nebo zákonem č. 87/2015 Sb. Zcela stranou ponechávám kritéria pro určení místní př́íslušnosti správních soudů v agendě porušení povinnosti veřejných funkcionářů, která měla jen krátkou účinnost. 
Do účinnosti tzv. velké novely byla $\mathrm{v} \S 7$ odst. 3 kritéria pro určení místní př́slušnosti ve věcech důchodového pojištění, důchodového zabezpečení a dávek podle zvláštních předpisů vyplácených společně s důchody podle místa bydliště, resp. faktického pobytu vůči obvodu krajského soudu. Podle odstavce 4 ve věcech nemocenského pojištění, pojistného na sociální zabezpečení a příspěvku na státní politiku zaměstnanosti byla místní př́ślušnost dána sídlem prvostupňového správního orgánu vůči obvodu krajského soudu. Současně byla pravidla pro určení obecné místní príslušnosti podle $\S 7$ odst. 2 dána podle sídla správního orgánu, který vydal rozhodnutí v posledním stupni, nebo jinak zasáhl do práv toho, kdo se u soudu domáhá soudní ochrany. Místní př́slušnost se v daném ohledu odvozovala od sídla žalovaného správního orgánu.

Takto nastavená kritéria pro určení místní př́islušnosti nicméně postupem času vedla jednak $\mathrm{k}$ disproporcím mezi oběma pražskými soudy, tj. Městským soudem v Praze a Krajským soudem v Praze, jakož i k extrémnímu zatížení Městského soudu v Praze, který v řadě agend vyřizoval více jak polovinu celostátního nápadu věcí. ${ }^{46}$

S účinností od 1. 1. 2012 se výše uvedená pravidla pro určení místní př́slušnosti změnila, přičemž hlavním důvodem $\mathrm{k}$ této změně bylo především snížení enormního zatížení správního úseku Městského soudu v Praze, což mělo za následek dlouhou dobu řízení ${ }^{47}$ před tímto soudem, a také pokud možno rozprostření některých agend mezi jednotlivé krajské soudy. Tohoto cíle mělo být dosaženo tím, že obecné pravidlo ve prospěch místa sídla správního orgánu, který rozhodl nebo zasáhl v posledním stupni, se změní na sídlo správního orgánu, který rozhodl nebo zasáhl ve stupni prvním. Toto pravidlo bylo již uplatňováno pro určení místní prŕíslušnosti ve věcech nemocenského pojištění, pojistného na sociální zabezpečení a př́íspěvku na státní politiku zaměstnanosti. Z uvedeného důvodu bylo zvláštní pravidlo z $§ 7$ odst. $4 \mathrm{~s}$. ř. s. opuštěno a zahrnuto pod obecné pravidlo pro určení místní př́ílušnosti v novém znění § 7 odst. $2 \mathrm{~s}$. ř. s.

Zvláštní kritéria pro určení místní příslušnosti $\mathrm{v} \S 7$ odst. 3 se již $\mathrm{s}$ účinností od 26. 11. 2012 změnila, a to na základě zákona č. 396/2012 Sb. Problémem se totiž ukázala být působnost nově zřizeného a pojatého Úřadu práce ČR jakožto orgánu s celostátní působností se sídlem $v$ Praze, nebot' v takovém prŕípadě by byla založena místní př́slušnost Městského soudu v Praze. ${ }^{48}$ Tím byl ilustrován príklad toho, jak záměry ohledně snížení zatížení soudu v oblasti správního soudnictví mohou být ve stejné době popřeny jinou právní úpravou a její koncepcí v oblasti organizace státní správy. Shora uvedenou novelou zákonodárce, a to včetně jejích přechodných ustanovení, ${ }^{49}$ poměrně brzy tento

\footnotetext{
46 Srov. ŠIMÍČEK, c. d., s. 59.

47 K délce řízení před soudem lze odkázat na statistiky dostupné na internetových stránkách Ministerstva spravedlnosti, kde jsou dostupné výroční statistické zprávy za roky 2016 až do současnosti (viz Statistiky z oblasti justice. In: justice.cz: katalog životnich situaci [online]. [cit. 2021-07-06]. Dostupné na: https:// www.justice.cz/web/msp/statisticke-udaje-z-oblasti-justice). Problematice délky soudního řízení obecně je věnována pozornost i na úrovni Rady Evropy, kde působí CEPEJ (viz Council of Europe European Commission for the efficiency of justice (CEPEJ) [online]. [cit. 2021-07-06]. Dostupné na: https://www. coe.int/en/web/cepej).

48 K tomu blíže srov. kupř. usnesení Nejvyššího správního soudu ze dne 16. 5. 2012, č. j. Nad 5/2012-34; nebo ŠIMÍČEK, c. d., s. 60.

49 Srov. čl. XXV zákona č. 396/2012 Sb.
} 
neuspokojivý stav vyřešil, a to výslovnou úpravou $\S 7$ odst. 3 s. ř. s., resp. rozšířením jeho znění o věci, které jsou součástí působnosti Úřadu práce ČR. ${ }^{50}$

V současné době jsou pravidla obsažená v soudním řádu správním založena na kombinaci místa sídla správního orgánu prvního stupně (který ovšem není žalovaným) $)^{51}$ a bydliště / faktického pobytu nebo sídla žalobce. Osobně jsem toho názoru, že daná právní úprava není přiliš přehledná. Případným změnám by ovšem měla předcházet analýza toho, v jakých počtech jsou využívána tato kritéria, a to i s ohledem na požadavek pokud možno rovnoměrného rozprostření soudního nápadu, ale také i z faktického hlediska př́stupu k soudu.

\section{VZÁJEMNÉ VZTAHY ORGANIZACE STÁTNÍ SPRÁVY A SPRÁVNÍHO SOUDNICTVÍ (Z POHLEDU MÍSTNÍ PŘÍSLUŠNOSTI)}

Shora uvedené dokládá, že vymezení místní prríslušnosti a s tím související územní působnost (správní obvod) v oblasti státní správy se úzce pojí s místní př́islušností soudů ve správním soudnictví. Obecné pravidlo pro určení místní příslušnosti správního soudu vychází z územní působnosti správního orgánu a jeho správního obvodu, resp. místa jeho sídla, které je vztaženo k tzv. soudnímu kraji. Zákonodárce se, a to i prostřednictvím tzv. fikce sídla správního orgánu, rozhodl ,„přiblížit“ některé správní orgány některým krajským soudům. Pozitivem může být větší znalost místních specifik, dostupnost soudu, rychlost při vzájemné komunikaci (zejména při doručování spisu) apod. Jakkoliv je také dán požadavek na předvídatelnost rozhodování ze strany soudů, neznamená to izolaci správních soudů při jejich rozhodovací činnosti, kdy rozprostření soudního nápadu má mj. vést k tomu, aby se soudy nepotýkaly ,jen se svými obvyklými““ správními orgány. ${ }^{52}$ Nevýhodou je ne vždy zcela snadné a bezproblémové určení místní příslušnosti správního soudu.

Nutno poznamenat, že toto není jediný problematický bod ve vztahu organizace státní správy a organizace správního soudnictví. Již výše byly naznačeny problémy ohledně vzájemné nezávislosti, či možná lépe neskladebnosti tzv. správních a soudních krajů. ${ }^{53}$ Tzv. soudní kraj totiž není totožný s kraji podle zákona č. 51/2020 Sb. (tedy ani

50 Podle usnesení Nejvyššího správního soudu ze dne 19. 11. 2020, č. j. Nad 155/2020-143, ustanovení $\$ 7$ odst. $3 \mathrm{~s}$. ř. s., které určuje zvláštní místní příslušnost krajského soudu pro určité kategorie věcí (například věcí důchodového pojištění), upravuje místní př́slušnost soudu jen v řízení o žalobě proti rozhodnutí správního orgánu podle $\S 65$ a násl. s. ř. s. Nelze jej tedy užít v jiných řízeních (například v řízeních o žalobě na ochranu proti nečinnosti podle $\S 79$ a násl. s. ř. s. a o žalobě na ochranu před nezákonným zásahem podle $\S 82$ a násl. s. ř. s.).

51 K vymezení žalovaného v řízení o žalobě proti rozhodnutí správního orgánu srov. $§ 69 \mathrm{~s}$. ř. s.

52 V. Šimíček se v této souvislosti zmiňuje o 8 daňových republikách, kdy dřivější neexistence Nejvyššího správního soudu ve spojení s místní příslušností vyvolávala ne vždy konzistentní př́istup judikatury. Srov. ŠIMÍČEK, $c$. d., s. 12 .

53 Shodně srov. PRŮCHA, P. Ke správnímu soudnictví po novelizaci soudního řádu správního, s účinností od 1. 1. 2012, aneb naplněná očekávání, promarněné příležitosti a otázky k perspektivní diskuzi. In: SLÁDEČEK, V. - MELOTÍKOVÁ, P. (eds.). Aktuální otázky správního soudnictví (zejména v souvislosti s novelou soudního řádu správního provedenou zákonem č. 303/2011 Sb.). Praha: Leges, 2021, s. 19. 
s kraji podle ústavního zákona č. 347/1997 Sb.), nýbrž zákon č. 6/2002 Sb., o soudech a soudcích, obsahuje v prrílohách vlastní vymezení organizace soudnictví. ${ }^{54}$

Na první pohled organizace správního soudnictví nesleduje organizaci státní správy. Neplatí to ovšem zcela bezvýjimečně, přihlédneme-li totiž ke skutečnosti, že tyto tzv. soudní kraje jsou totožné s původními tzv. správními kraji, jak byly založeny reformou v roce 1960 a shora uvedeným zákonem č. 36/1960 Sb. Často se v souvislosti s kraji z roku 1960 hovořilo jako o dvojím krajském dělení nebo o „superkrajích“, a to proto, aby se odlišily od krajů - vyšších územně samosprávných celků podle ústavního zákona č. 347/1997 Sb. Zatímco na počátku správní soudnictví následovalo, alespoň co do krajské úrovně, organizaci státní správy, v současné době již tomu tak není. V praxi nejsou výjimečné př́pady, kdy jeden krajský soud přezkoumává rozhodnutí několika krajských úřadů, což samo o sobě není nutně problematické. Potíž nastává, pokud vůči jednomu krajskému úradu je ,zaměřena pozornost“ hned ze strany 3 krajských soudů. ${ }^{55}$ To mj. klade vysoké nároky na stabilitu judikatury.

Právní úprava místní príslušnosti správního soudnictví vychází z organizace státní správy tím, že ji zohledňuje, nicméně není na ní zcela závislá, resp. není jí podřízena.

V současné době zaznívají hlasy volající po revizi počtu krajských správních soudů. Řešením je zvýšení počtu těchto soudů a přibližžení tzv. soudních krajů krajům správním. Každý kraj by tak měl mít „svůj“ krajský soud. Je nicméně nutno zdůraznit, že takováto zjednodušující tvrzení jsou dosti zavádějící. Předně, krajský soud je orgánem státu pro výkon (nezávislého) soudnictví a současně „kraj nedělá krajem“ sídlo žádného státního orgánu, včetně krajského soudu. Dokonce se domnívám, že v tomto ohledu se jistá nesourodost tzv. soudních a správních krajů může jevit jako př́íhodná a podporující nezávislost soudnictví. Stávající stav je jistým kompromisem, kdy v některých př́padech skladebnost tzv. soudních a správních krajů dána je, a jindy nikoliv. Jinou možností je vybudování krajských správních soudů na zcela jiné organizační bázi, což pochopitelně bude muset vycházet z jejich institucionální nezávislosti a samostatnosti na krajských soudech v rámci obecného soudnictví. Otázkou je počet takových soudů ${ }^{56}$ a vymezení jejich územního obvodu.

\section{ZÁVĚR}

Jakkoliv se nabízí, že by organizace správního soudnictví měla být zcela nezávislá na organizaci státní správy, jsem spíše toho názoru, že by v základních rysech mohla a měla organizace správního soudnictví (ná)sledovat organizaci státní správy

${ }^{54} \mathrm{~K}$ problematice vymezení tzv. soudních okresů srov. LOUTOCKÝ, V. K vymezení soudních okresů. Soudce. 2021 , roč. 23 , č. 5 , s. 14 a násl.

55 Ukázkovým př́ikladem je Kraj Vysočina a jeho správní obvod/území a skutečnost, že spadá pod území soudních krajů Krajského soudu v Českých Budějovicích, Krajského soudu v Hradci Králové a Krajského soudu v Brně.

56 M. Mazanec vyjádřil myšlenku existence 3 až 4 správních soudů prvního stupně - viz Mazanec, šéf českého Najvyššieho správneho súdu: Ste krok pred Českom. In: Pravda [online]. 27. 5.2021 [cit. 2021-07-06]. Dostupné na https://spravy.pravda.sk/domace/clanok/589286-mazanec-so-spravnym-sudom-ste-krok -pred-ceskom/. 
(opačně by to však již platit nemělo), a to v kontextu pravidel pro určení místní příslušnosti krajských soudů. Důvodem je „,blízkost“ obou orgánů z hlediska žalobce a také vyšší pravděpodobnost rychlejší komunikace. Zmínit lze v této souvislosti vcelku známý závěr Ústavního soudu, podle něhož je věcí státu, jak hodlá organizovat soudnictví, pochopitelně při zohlednění základních práv a svobod. ${ }^{57}$

Pokud by kritéria místní př́slušnosti správních soudů neměla souviset se sídly a obvody působnosti správních orgánů (lhostejno nyní, zda v prvním nebo posledním stupni), nýbrž by reflektovala „pobyt/sídlo“ žalobce, lze si uvedený př́ístup představit. Nezbytné je ovšem disponovat přesnějšími daty z hlediska rozložení nápadu a jeho struktury.

V prŕíspěvku jsem poukázal na proměny v organizaci státní správy, ve spojení s proměnami ohledně místní př́slušnosti správních soudů. Zatímco důvodem pro změny v územní organizaci státní správy bylo odstranění duplicity krajů, skladebnost územně správního členění státu, jakož i dokončení územní reformy veřejné správy a „sjednoceni'“ její podoby po územní stránce z hlediska státní správy a samosprávy, v př́ípadě správního soudnictví byly změny vedeny především za účelem snížení zatížení správního úseku Městského soudu v Praze, a tím i délky řízení před tímto soudem, jakož i rovnoměrného rozprostření soudní agendy, aby nedocházelo k nedůvodné „specializaci“. V souvislosti s tím došlo také k personálnímu posílení.

Jsem toho názoru, že stávající organizace krajských správních soudů není uspokojivá. Jako řešení vidím vytvoření zcela samostatných správních soudů prvního stupně, přičemž další otázkou je jejich počet a umístění, které by primárně nemuselo tolik sledovat organizaci státní (či veřejné správy), nýbrž množství soudního nápadu, a to jak stávajícího, tak především budoucího. Domnívám se, že v 21. století, i s ohledem na dostupnost moderních technologií, již není pro správní soudnictví (i pro jeho posteriorní či přezkumný charakter) klíčovým požadavkem přímý př́stup $\mathrm{k}$ soudu v rovině jeho geografické blízkosti (jakkoliv to zcela jistě přináší výhody) k účastníkům ř́zení, zejména potom k žalobci. Klíčové naopak je, aby jednotlivé správní soudy prvního stupně byly vzájemně souměřitelné a aby u nich nedocházelo $\mathrm{k}$ nedůvodným výkyvům, jak z hlediska počtu nápadu, složitosti věcí, tak rychlosti projednání a rozhodnutí věcí, ale také v kvalitě takové rozhodovací činnosti.

JUDr. Lukáš Potěšil, Ph.D.

Právnická fakulta Masarykovy univerzity

Lukas.Potesil@law.muni.cz

57 Srov. nález ze dne 10. 11. 1998, sp. zn. IV. ÚS 358/98. 